\title{
Placental nitrosative stress and in utero exposure to particulate matter
}

\author{
Nelly Saenen ${ }^{1 *}$, Karen Vrijens ${ }^{1}$, Bram Janssen ${ }^{1}$, Narjes Madhloum¹, Martien Peusens ${ }^{1}$, Wilfried Gyselaers ${ }^{2}$, \\ Charlotte Vanpoucke ${ }^{3}$, Wouter Lefebvre ${ }^{4}$, Harry Roels ${ }^{1}$, Tim Nawrot $^{1}$ \\ From Methods in Epidemiology Symposium \\ Leuven, Belgium. 17 September 2015
}

\section{Background and aims}

A wide variety of adverse health effects on both fetuses and neonates have been ascribed to particulate matter (PM) air pollution. Recent evidence suggests that PM exposure results in increased oxidative and nitrosative stress. In the ENVIRONAGE birth cohort, we investigated the association of placental 3-nitrotyrosine (3-NT) with $\mathrm{PM}$ exposure during various time windows of pregnancy.

\section{Methods}

3-NT levels were measured in 341 placental tissue samples, selected from the ENVIRONAGE birth cohort, using a competitive ELISA. Daily $\mathrm{PM}_{10}$ and $\mathrm{PM}_{2.5}$ exposure levels were interpolated for each mother's residential address using a spatiotemporal interpolation method in combination with a dispersion model. Multiple linear regression models were used to assess the association between 3-NT and PM exposure for different pregnancy windows.

\section{Results}

The placental 3-NT level, adjusted for gender, gestational age, maternal age, pre-gestational BMI, smoking status, and warm or cold period at delivery, raised with $31.0 \%(p=0.0008)$ for an interquartile range increment in whole pregnancy $\mathrm{PM}_{2.5}$ exposure. The association was driven by $\mathrm{PM}_{2.5}$ exposure during the first trimester $(25.7 \%, p=0.01)$ and second trimester $(37.0 \%, p=$ $0.003)$ of pregnancy.

\section{Conclusions}

We observed a positive association between 3-NT levels in the placenta and $\mathrm{PM}_{2.5}$ exposure during whole pregnancy.

${ }^{1}$ Hasselt University, Diepenbeek, Belgium

Full list of author information is available at the end of the article
Our findings, which are in line with experimental evidence on cigarette smoke and diesel exhaust exposure, indicate the influence of PM exposure during pregnancy on placental oxidative stress. The impact of placental 3-NT with regard to PM exposure on newborn's health needs further elucidation.

\begin{abstract}
Authors' details
${ }^{1}$ Hasselt University, Diepenbeek, Belgium. ${ }^{2}$ Department of Obstetrics, EastLimburg Hospital, Genk, Belgium. ${ }^{3}$ Belgian Interregional Environment Agency, Brussles, Belgium. ${ }^{4}$ Flemish Institute for Technological Research (VITO), Mol, Belgium.
\end{abstract}

Published: 17 September 2015

doi:10.1186/2049-3258-73-S1-P17

Cite this article as: Saenen et al:: Placental nitrosative stress and in utero exposure to particulate matter. Archives of Public Health 2015 73(Suppl 1):P17.

\author{
Submit your next manuscript to BioMed Central \\ and take full advantage of: \\ - Convenient online submission \\ - Thorough peer review \\ - No space constraints or color figure charges \\ - Immediate publication on acceptance \\ - Inclusion in PubMed, CAS, Scopus and Google Scholar \\ - Research which is freely available for redistribution

